\section{Playing the numbers game}

\section{London}

A REPORT from the House of Lords select committee on science and technology charges that official government figures for British research spending paint a misleadingly favourable picture, and concludes that "as a nation we are investing too little in civil R\&D and the situation is getting worse".

The UK defence research and development (R\&D) budget, at $£ 2,300$ million, accounts for half of Britain's total R\&D effort, a proportion exceeded only by the United States. But the Lords report, "Definitions of Research and Development", argues that up to half of this money goes to product development rather than innovative work. Internationally accepted definitions used by the Organization for Economic Cooperation and Development exclude product development work from R\&D accounting.

The report also shows how ministers quote carefully selected statistics to compare British research spending with that of other nations. If, as the committee recommends, expenditure is expressed as a percentage of gross domestic product (GDP), and if defence spending is removed, British R\&D spending comes out below West Germany, France and Japan, but above the United States. And if private sector spending is included, Britain falls behind all four nations.

Professor Denis Noble, from the University of Oxford and president of the Save British Science pressure group, says the position of British civil science is even worse than the "bald statistics" imply. Although the US government's civil science budget compares poorly to Britain's, using the select committee's indicator, Noble says that whereas "a very substantial fraction" of US military research spending gets through to the civil sector, almost all British defence research is done 'in house' or contracted to defence procurement companies.

The select committee's report singles out the weakness of private sector research for particular criticism. But an international survey of government-supported academic research, summarized in the next issue of Science and Public Policy, provides a similarly gloomy analysis of British government spending.

Ben Martin, John Irvine and Phoebe Isard, from the University of Sussex, found that British government spending in the seven years up to 1987 , at around 0.4 per cent of GDP, averaged only four fifths of that in France, West Germany and the Netherlands. The US and Japanese governments spent a smaller proportion of GDP on academic research even than Britain. But these countries have large private university sectors, so may be less

relevant for comparison with the UK. The study was paid for by the UK Advisory Board for the Research Councils (ABRC) and the US National Science Foundation (NSF), and updates an earlier study funded by the ABRC (see Nature 323, 591; 1986).

British government support in 1987 for environmental science, mathematics, computing and engineering compared favourably with France, West Germany and the Netherlands. But the Sussex team calculate that an extra $\$ 500$ million should have been spent in 1987 to bring UK spending on physical and life sciences, as a proportion of GDP, in line with the other three European nations surveyed. Increases to the British science budget in 1988 and 1989 may have remedied this deficiency somewhat, but the French and German governments have also increased spending.

\section{BRAZILIAN ECONOMIC CRISIS}

\section{São Paulo}

Aвout 15,000 graduate students in Brazil are still waiting for their stipends, some 50 days after their last payment. Another 2,200 graduate students abroad are a little luckier and have received their April payments, but they are now worrying about their chances of receiving money for May. The nationwide evaluation of postgraduate courses has been abandoned.

These are some of the effects of Brazil's new economic austerity measures and the reform of federal bureaucracy. The innocent victim was a Ministry of Education grants agency known as the Coordinating Agency for Advanced Training of HighLevel Personnel or CAPES. Last week, the agency was not coordinating much besides its own survival.

CAPES was simply forgotten by the planners of the administrative reform, and was accordingly considered extinguished by a provisional measure, number 150 . The Minister of Education, Carlos Chiarelli, tried to recreate the agency, but could do nothing immediately as action was required by Congress.

An amendment to measure 150 was finally passed and CAPES was reborn. But in the meantime, students received no money and postgraduate programmes had no coordinating body.

As a protest, graduate students at the University of São Paulo took to begging money from drivers at traffic lights at the campus. But CAPES new directrice, anthropologist Eunice Ribeiro Durham, says that funds will be available again soon. Durham is a former vice-president of the Brazilian Society for the Progress of

\title{
Graduates see grants vanish
}

Sir David Phillips, chairman of the ABRC, confirms that the survey's results will be used as a basis for discussions with the Department of Education and Science on the size of next year's science budget. Ministers may argue that Britain does not need to spend a similar proportion of GDP to other European countries to maintain a competitive civil science base. But a second paper in the same issue of Science and Public Policy shows that the British share of world output and citations of basic scientific research papers is declining.

In collaboration with Computer Horizons Inc. (CHI), from New Jersey, and Diamond Systems, a British company, Martin and Irvine surveyed the CHI/NSF Science Literature Indicators Database. Martin and Irvine conclude that "British performance is weak and deteriorating in several scientific areas . . important for future industrial competiveness", including solid state physics, polymer chemistry and computer science.
Science (SBPC). That and her friendship with the Secretary of Science and Technology, Jose Goldemberg, give hope to researchers that help may actually arrive.

At the same time, the new economic measures are wreaking havoc among the scientific societies. The 36 th Brazilian Genetics Society Meeting had to be cancelled last month because the society could not obtain the resources it had counted upon - the government has blocked access to 80 per cent of the money in all bank accounts, savings and investment accounts as part of its drastic economic plan.

The president of the Genetics Society, Francisco Moura Duarte, has had to send telegrams and letters to the 65 foreign researchers invited to the meeting. The meeting, scheduled for 28 to 31 May, also included the first workshop of the LatinAmerican Association of Environmental Mutagenis, Carcinogenesis and Teratogenesis.

A failure of the National Council for Scientific and Technological Development $(\mathrm{CNPq})$ to provide sufficient money was partly responsible for the cancellation of the conference. But Duarte is particularly angry with the federal government. The Secretary of Science and Technology, José Goldemberg, had promised to try to release the money held by the scientific societies from government restrictions. Duarte's frustration led him to say that the military presidents who ruled Brazil from a coup in 1964 till 1985 had been more "sensible" in their attitude towards science than the presidents of the democratic period.
Ricardo Bonalume 